\title{
Introducing the E-newspaper: Identifying Initial Target Groups
}

\author{
Carina Ihlström Eriksson, Maria Åkesson, Jesper Svensson \\ and Tobias Fredberg \\ Halmstad University and Chalmers University
}

\begin{abstract}
This article investigates how audience groups differ with respect to the adoption of new media services. The authors expand the existing framework of early adopters, which is heavily directed towards the technological aspects of a product, by including users that are more interested in the social and content-related aspects of media services. The objective is to identify and explore important audience groups that can be used as initial target groups for the introduction of the enewspaper (a newspaper published on e-paper technology). Data was collected from in total 2976 respondents through the web sites of three Swedish newspapers.
\end{abstract}

KEY WORDS: innovations, consumer adoption, e-newspapers, e-paper

Organizations face a dilemma with regards to the potential business opportunities when they develop a new technology or adapt to a new technological standard. They can either disregard market signals and make a "proposal" to the market in terms of a new product (Verganti, 2005 ), or they can orient themselves to consumers preferences. In the first case, the risk of failure is very high. In the second case, there is a risk that the consumer orientation creates inertia for change - listening to current consumers may conserve organizational practices (Dahlsten, 2004; Danneels, 2003). To overcome the dilemma, techniques have been developed to analyze early market signals. In technology driven companies, it becomes natural to analyze consumers' adoption of technological aspects of a new product. The perhaps most influential of these frameworks is Rogers' (1995) notion of early adopters. These consumers are some of the first to use a technology or a product and become important as a test bed for new innovations. It has therefore been in the interest of companies and market research organisations to identify these early adopters and test new ideas on them.

Copyright @ 2007 Journal of Media Business Studies. Carina Ihlstrom Eriksson, Maria Åkesson, Jesper Svensson and Tobias Fredberg, "Introducing the E-newspaper: Identifying Initial Target Groups," 4(3):41-62 (2007). 
This was the case in the planned introduction of the e-newspaper, which was studied in a two-year collaborative research project called DigiNews, including several major technology firms, newspaper organizations and universities across Europe. The intention of the involved newspaper organizations was to use consumer research such as the early adopter approach to discover preferences of future consumers and use them as input for further development of the e-newspaper. The e-newspaper is a newspaper published on electronic paper (e-paper) - a technology which allows the same reader experience as paper such as high contrast and the possibility to read in sunlight. The e-newspaper is expected to become a convergence of the printed newspaper and the online newspaper (Ihlström et al., 2004). It has attracted the interest of newspaper organizations since the potential replacement of the printed edition in the future would dramatically reduce production and distribution costs.

In the case of the e-newspaper introduction, not only the technological aspects are important. The content as well as the social aspects of the innovation are central for its proliferation, since new media services are being developed for the device. This phenomena demand a different approach to analysing consumer groups. Given this situation, it is not enough to focus solely on theories of technology adoption when planning the parallel introduction of a new technology and media services.

In this paper we propose an approach that considers both technology adoption and media consumption.

Our overall research question is: How can we combine adoption theories with media consumption aspects to identify audience groups for parallel introduction of new technology and media services? The objective of this paper is to identify and explore important consumer groups that can be used as initial target groups for the introduction of the enewspaper.

For this purpose the paper is structured as follows: Section 2 describes the DigiNews case and is followed by a theory discussion in section 3. The research method is then described in section 4, the findings and analysis are presented in section 5 and section 6 concludes the paper with a discussion of the findings.

\section{THE DIGINEWS CASE}

DigiNews (ITEA 03015) is a recent European project that was finalized during the summer of 2006 and the project results were presented during the fall of 2006. The project started in 2004 after an initiative taken by Philips Applied technologies and the Swedish newspaper publishers association. Partners were European newspaper organizations (e.g. Aftonbladet, De Telegraaf, Le Monde, Concentra Media), technology 
developers (e.g. Ibermatica, Robotiker), and Universities (e.g. Halmstad University, KTH, KUL Leuven).

The DigiNews project aimed at defining, architecting and demonstrating a solution of a digital newspaper. The solution included all parts needed to produce, distribute and consume digital news, i.e. all steps from publisher to reader. The project also explored ways to maximize the chances of a successful introduction to the market; this included the creation of different business plans and strategies. To reach the project goal and to ensure acceptance of the proposed digital newspaper system by the various stakeholders, three points-of-views were taken: user, business, and technology.

The project had the ambition to create a digital newspaper acceptable to a wide audience, by exploiting the potential of this digital media. Since the e-paper terminal used in the project had a much smaller display than the traditional printed newspaper, one challenge was to make this smaller format acceptable to the reader and to provide a user experience that was similar to reading a printed newspaper. Another challenge was to create a user interface that was easy to use, not only by computerexperienced people, but for everybody.

During the project different e-newspaper prototypes (Figure 1) were developed for PC:s and tablet PC:s to be able to test conceptual ideas. These interactive prototypes were developed together with newspaper designers and used content from the newspaper partners. The prototypes allowed developers to test alternatives regarding for example navigation, the design of information structure and other interaction aspects.

\section{Figure 1: Prototypes of Aftonbladet, Göteborgs-Posten and Sundsvalls Tidning}
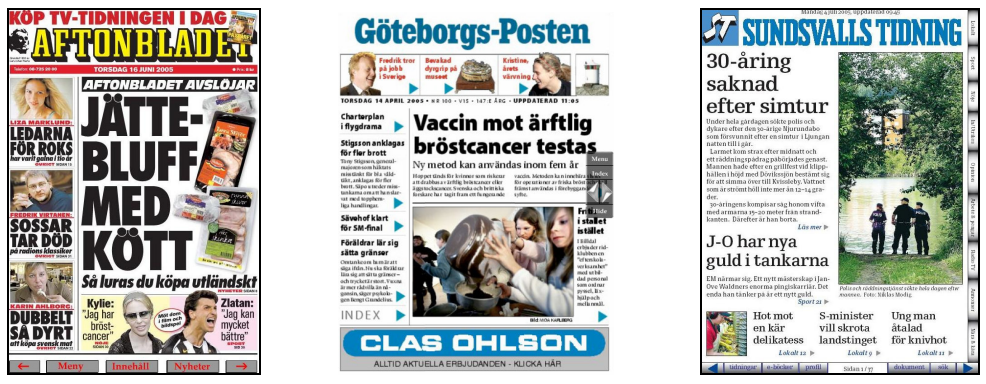

\section{E-paper Technology}

One of the biggest advantages of using the e-paper technology is the readability of the display. E-paper is a wide-range term for a number of different technologies that can be used to produce displays; many of them have properties that can be compared with print on paper.

The technology works essentially in the same way, but instead of printing black dots on paper, the print is made electronically. Compared 
to transmissive displays such as LCD and TFT displays, e-paper is a reflective display technology. It has no backlight therefore the same reading properties as printed paper are granted. Transmissive displays that use backlight are in many cases almost unreadable in full sunlight. Many e-paper technologies have a high resolution that is comparable with the resolution used in traditional newspapers (170 dots per inch or more). This resolution is superior to the standard 72 dpi that is used on most of today's computer displays. The electronically made print also enables e-paper the same viewing angle as in any printed material. Another advantage of the technology is the low power consumption; power is only needed when the display is updated.

E-paper technology is developing rapidly and many actors invest in plastic electronics and produce new prototypes and products. Sony was the first company that launched an e-paper product on the Japanese market, the Sony LIBRIé. During autumn of 2006 Sony launched another e-reader, the Sony Reader, focused on the U.S. market (Sony, 2006). iRex Technology BV was the second actor that launched a commercially available e-paper reading device in April 2006 called the iLiad (iRex, 2006). Tianjin Jinke Electronics Co., LTD has several e-book products based on the same technology as Sony and iRex. The Hanlin ebooks also have almost the same specification as the Sony Reader. The company presents a roadmap with numerous new products including devices with bigger displays and dual displays that are planned to meet the market during 2007 (Tianjin Jinke, 2006). E-paper technology is also used in other products such as clocks and displays for mobile phones, Citizen, Seiko and Motorola have launched products based on e-paper displays. Table 1 (on the next page) presents a brief summary of some of the competing e-paper technologies under development.

In the DigiNews project, the iRex iLiad platform was used to present a solution for an electronic newspaper.

\section{Potential Impact of E-newspaper Introduction}

In recent years the newspaper industry has experienced a decline in both advertising and subscription revenues (The Economist, August 26, 2006) which have lead them to seek other possible revenue opportunities, mainly exploring the digital arena.

Due to the obvious benefits of the e-paper technology described above, i.e. the resemblance of paper, the newspaper industry is taking an active interest in the development of the technology through projects like the DigiNews and IFRAs eNews initiative (IFRA, 2006).

If the printed newspaper could be replaced with an e-newspaper it would dramatically reduce production and distribution costs for the newspaper organizations. Several newspapers in Sweden are about to prospect new printing presses. Publishing the e-newspaper eliminates this stage of the newspaper production process which is costly and puts strains on deadlines, too. Many newspapers in Sweden have subscribers 
Table 1: Summary of E-paper Technologies

\begin{tabular}{|c|c|c|c|}
\hline $\begin{array}{l}\text { Developing } \\
\text { company }\end{array}$ & $\begin{array}{c}\text { Properties of the } \\
\text { E-paper }\end{array}$ & $\begin{array}{c}\text { Expected Release } \\
\text { Date }\end{array}$ & Source \\
\hline Fujitsu & $\begin{array}{l}\text { Bendable and vivid } \\
\text { color display. }\end{array}$ & $\begin{array}{l}\text { Between April } 2006 \\
\text { and March } 2007\end{array}$ & Fujitsu (2005) \\
\hline Plastic Logic & $\begin{array}{l}\text { Printing on thin } \\
\text { flexible plastic, } \\
\text { production aimed at } \\
\text { high volume and } \\
\text { low cost. }\end{array}$ & - & Plastic Logic (2006) \\
\hline Polymer Vision & Rollable display. & - & Polymer Vision (2006) \\
\hline Hewlett Packard & $\begin{array}{l}\text { Color display that is } \\
\text { light, thin and } \\
\text { flexible at a low } \\
\text { production cost. }\end{array}$ & - & Sfgate.com (2006) \\
\hline Hitachi Ltd. & $\begin{array}{l}\text { 13.1-inch display, } \\
\text { low resolution with } \\
\text { eight colors. }\end{array}$ & March 2008 & Techworld.com (2006) \\
\hline Siemens & $\begin{array}{l}\text { Thin color display, } \\
\text { able to show } \\
\text { animations. }\end{array}$ & 2007 & Vnunet.com (2006) \\
\hline
\end{tabular}

in sparsely populated areas which creates very high distribution costs. Delivering the newspaper electronically would reduce the distribution cost but also create new opportunities to reach potential readers all over the world. Furthermore, an e-newspaper allows for several editions a day or continuously updates like on the web.

The Chinese Yantai Daily Media Group is the first newspaper organization that has launched the e-newspaper commercially. The Chinese media group started in September 2006 to publish three newspapers on the iRex iLiad device. According to a press release from iRex, the President of Yantai Daily Media Group is "... convinced that this method of mobile digital printed media consumption will draw a lot of new users to reading our newspaper content" (iRex, 2006).

\section{THEORETICAL BACKGROUND}

Technological shifts in the media business during the last 100 years have been of two kinds: the process improvement in the production of newspapers and the introduction of new media such as radio, television and the Internet. When a new technology or innovation has been included in the newspaper world, it has not always been an easy process. Such was the case with desktop publishing and pagination systems that made it possible to edit and layout the newspaper directly on the computer screen (Singer et al., 1999). The pagination systems were at introduction accused of creating more homogeneity among newspapers, and for reducing the role of reporters to data entry workers (Underwood, 1995). Another example is the introduction of online newspapers which initially was not embraced by all journalists (Ihlström \& Palmer, 2002). 
In the history of media the development of new technologies has been followed by developments in content. For example, newspapers did not disappear as a result of the introduction of radio or television as it was feared. Media forms seem to have complemented each other, as they have tended to take different roles (Weibull \& Wadbring, 2000). Ihlström and Henfridsson (2004) argue that different genres have developed in different media forms, and Ziv (2005) argues that new content and services were key factors in making consumers adapt to new mobile devices. Media products include both technological and content related aspects. The medium (paper, radio, television, Internet, PDA etc.) itself carries the actual media service which becomes the focus of attention for potential consumers.

This means that consumers take on new and different roles in the relation to the media (Webster, 1998; Deery, 2003; Fredberg \& Ollila, 2005). Media services have important social connotations through their content and their use (e.g. Bazalgette, 2005; Deery, 2003; Park, 1923). The members of the community formed around the media service (Johansson, 2002) become co-creators (Prahalad \& Ramaswamy, 2003), and the community itself is an important part of the service (Hagel III \& Armstrong, 1997).

To our knowledge, there exists no comprehensive overview of how newspaper organizations reason with regards to methods for analysing new markets for media services. Also, the media industry does not have a tradition of product development to the same extent as other industries. An example is the fact that several of the major European newspaper organizations do not have R\&D departments.

To the extent that methods for analysing future markets are used, developers seem to reason mostly using Rogers' (1995) framework of early adopters. These consumers are some of the first to use a new product or innovation, and therefore have an important role in marketing the innovation to a greater mass of people. People that think about adopting the new technology turn to the early adopters for advice. Since early adopters are not too far ahead in the adoption curve, their preferences can serve as a proxy for those of the majority of consumers. Companies and researchers alike have therefore been focusing on this group to understand their preferences, as they would increase our understanding of the preference of the greater mass of consumers. The rationale is that if the group can be defined, then its constituents' preferences can be researched, and guidance for further development be generated. Rogers' framework on the diffusion of innovations primarily addresses the adoption rate of new technology and hence builds on a set of assumptions on people's preferences for the technological aspects of a product.

With Rogers, the adoption rate over time is determined by the attitudes of the members of the social systems towards the characteristics of the innovation. These characteristics have five sources: 
- Relative advantage - how much better potential adopters perceive the innovation to be in comparison to the current products or ideas. The advantage may for example be economical, in terms of social prestige, convenience or satisfaction.

- Compatibility - how consistent the innovation is with values, experiences, and needs of the potential adopters.

- Complexity - how difficult it is to understand and use the innovation.

- Trialability - how easy potential adopters may experiment with the product to learn to understand it.

- Observability - how evident the contribution of the innovation is to others.

To explain the diffusion of innovations, Rogers differentiates the rate of adoption among five groups of customers (or members of the social group/system): innovators, early adopters, early majority, late majority, and laggards.

Simply put, these aspects primarily relate to the technological aspects of a product. For many products, technological aspects are the easiest to measure. As a consequence, their characteristics can be used as arguments for managers or consumers wanting to make rational decisions. However, the technological aspect of a new product is not the only one that consumers take into consideration when making a purchase decision. Other aspects such as status (Vigneron \& Johnson 1999), information value (Balasubramanian \& Mahajan 2001), or experience (Arnould \& Price 1993; Pine II \& Gilmore 1999; Calder \& Malthouse 2004) of a product or service also play an important role. A framework using only technological aspects only delivers partial answers as to why people adopt something. From a company perspective, this means that a reliance on the technology, early adopters will give one kind of development direction as to whether people will or will not adopt certain products or product characteristics.

The reliance on content in the development of new business creates a need to find an alternative approach to the analysis of how new services are introduced and why they become successful. Whereas Rogers (1995) relies heavily on the technological aspects of the product, new media innovations will include content aspects and media habits that cannot be ignored. The reliance on content and community related aspects in the development of new services make the media industry suitable for the development of another measure of innovation adoption. It is also of importance to the management of product development in newspaper organizations. Whereas a technologically driven company can rely on measurements such as early adopters, media companies need to put a heavier emphasis on content-aspects and media habits. We therefore argue that the case of a parallel introduction of new technology and media services needs further considerations such as media consumption issues. 
Among media consumers, some are more active than others in taking part of and contributing to the media content (cf. Webster, 1998; Singer 2002). In this paper, we have chosen to call them active media consumers. The active media consumers have a focus on the contentrelated and the participatory aspects of the product and are in that sense the content side equivalents to early adopters. They are not necessarily early adopters of a product in Rogers' (1995) meaning, but a kind of "expert consumers" (for a discussion, see Bettman \& Sujan 1987). They are more advanced in their media consumption, but are not likely to be homogenous with regards to media content preferences. Instead of high interest and consumption of new technology they have a high interest and consumption of new media that is accessible anywhere and any time. Depending on the kind of innovation which is tested and introduced, one group or the other may be more important.

In the case of the e-newspaper, the introduction has a technological aspect as well as a content-related aspect, since new media services are being developed for the device. Early adopters may be important for the introduction of the device itself, i.e. the technology, whereas active media consumers may be interested in the introduction of new media services.

\section{METHOD}

In order to identify consumer groups for a parallel introduction of both a new technology and media services a qualitative approach has been taken (Hair et al., 2005). This study can be labeled as opinion research (Jenkins, 1985) with the objective to gather data on attitudes, opinions, impressions and beliefs of human subjects. This was accomplished by using a questionnaire.

\section{Data Collection}

We choose to use online questionnaires because that allowed us to provide information for the respondents to obtain an understanding of the e-newspaper concept. Since we assumed that the e-newspaper concept was unknown to most of the potential respondents we provided them with the possibilities to:

- read more about e-paper technology,

- watch three concept videos (see below), and

- explore the e-newspaper prototype of the corresponding newspaper.

Another reason for choosing online questionnaires is that web samples can be as representative, or even more representative than traditionally collected samples because of the heterogeneity of the online population (Buchanan and Smith, 1999). Admittedly, there are inherent problems in controlling whom responds to online questionnaires. Control 
for cases with multiple submissions from the same IP number was excluded in the data collection.

We presented the questionnaire at the news sites of the three Swedish newspapers that we have collaborated with in developing enewspaper prototypes within the DigiNews project, i.e. Aftonbladet, Göteborgs-Posten and Sundsvalls Tidning. Aftonbladet is a quality tabloid with the most visited news site in Sweden, Göteborgs-Posten is a local morning paper covering Göteborg (the second largest city in Sweden) and its surroundings, and Sundsvalls Tidning is a local morning paper in the north of Sweden.

In parallel with the DigiNews project three short concept movies of future e-newspaper use were developed to further illustrate the potential of the e-newspaper. These movies where created in collaboration with SVID (Stiftelsen Svensk Industridesign), the design company Propeller $\mathrm{AB}$ and the Swedish Newspaper Publishers' Association. The movies envisioned the benefits of the e-newspaper for three different personas: the business women, the student and the senior citizen (identified as potential target groups in the DigiNews project). Close ups on the designed user interface together with examples of functions demonstrated the future e-newspaper in detail. The scenarios were based on preferences articulated by respondents in workshops and interviews in the early stage of the DigiNews project and showed how a future enewspaper could support the media consumption of the three personas in different contexts. These movies were presented to the respondents to further illustrate the e-newspaper concept.

Three approaches for presenting the questionnaire were used in the study, a) a newspaper article explaining the e-newspaper concept at Aftonbladet's www.aftonbladet.se, b) a banner at Göteborgs-Posten's www.gp.se, and c) a pop-up window at Sundsvalls Tidning's www.st.nu.

a) In conjunction to the article, links to the three concept videos and to the Aftonbladet e-newspaper prototype were presented. There was also a written invitation to participate in the questionnaire presented together with a link to the starting page of the questionnaire. The article was placed on the front page of www.aftonbladet.se on April $7^{\text {th }}$ (11.23 AM), was moved to the IT section on April 10 th and removed on April 11 th (5.00 PM). At www.aftonbladet.se, 3757 respondents answered the questionnaire.

b) The banner (Figure 2) read "Do you want to influence the future enewspaper? Click here!" By clicking the banner the visitor was directed to the starting page of the questionnaire. The banner was placed on www.gp.se between April $7^{\text {th }}$ (10.23 AM) to April $12^{\text {th }}(07.54 \mathrm{AM})$, only resulting in 135 respondents.

c) A full size pop-up window was presented each time a visitor entered the front page at www.st.nu between April $7^{\text {th }}(12.10$ 
AM) to April $12^{\text {th }}$ (09.15 AM) resulting in 447 respondents. The pop-up window presented the starting page of the questionnaire.

Figure 2: Banner at www.gp.se

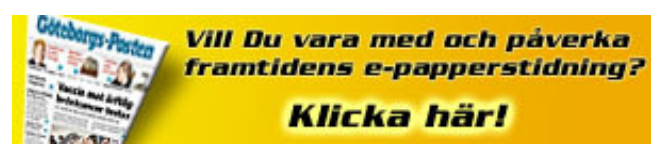

The questionnaire consisted of 127 questions in total, divided in 4 different parts, i.e. background questions, business models, e-newspaper preferences and preferences of mobile services. The first part contained 20 questions with regard to demographic nature (5), media consumption (3), technology use (5) and the use of mobile services (7). Question 14 was the initial question about the use of mobile services and also controlled whether section 4 (mobile services) should be presented to the respondent or not. The second part consisted of 40 questions concerning business models for the e-newspaper while the third part 26 questions about e-newspaper preferences as well as several key questions for identifying users groups. Finally, the last part consisted of 41 questions with regard to preferences for mobile services on PDAs and mobile phones. Many of the questions where of multiple choice nature, however, several open questions were included as well.

In this paper we only report about part one and three. Only respondents who pushed the submit button at each section of the questionnaire were included in this survey. As can be seen in Table 2, 2976 respondents answered the questions that are analyzed in this paper. In total, 4339 readers answered fully or partly to the questionnaire.

Table 2: Newspapers Hosts for Questionnaires

\begin{tabular}{|l|c|c|c|c|}
\hline Newspaper & URL & $\begin{array}{c}\text { Unique } \\
\text { Visitors per } \\
\text { Day }\end{array}$ & $\begin{array}{c}\text { Total No. of } \\
\text { Respondents }\end{array}$ & $\begin{array}{c}\text { No. of } \\
\text { Respondents } \\
\text { for This Paper }\end{array}$ \\
\cline { 2 - 5 } & aftonbladet.se & $1,200,000$ & 3,757 & 2,626 \\
\hline Aftonbladet & gp.se & 41,500 & 135 & 90 \\
\hline $\begin{array}{l}\text { Göteborgs- } \\
\text { Posten }\end{array}$ & st.nu & 14,500 & 447 & 260 \\
\hline $\begin{array}{l}\text { Sundsvalls } \\
\text { Tidning }\end{array}$ & \multicolumn{4}{|l}{} \\
\hline
\end{tabular}

\section{Data Analysis}

We identified early adopters of technology from 5 key questions and active media consumers from 6 key questions in section one and three of the questionnaire. The questions to identify early adopters concerned possession of and interest in new technology as well as questions about if the respondents talk about technology and is asked about new technology. The questions to identify active media consumers concerned 
media habits, consumption and interest in media in general. The respondents were also asked if they often discuss news and if they believe they are better informed about news than people in general.

The dataset was split in four groups in the analysis; early adopters, active media consumers, the above who were identified as both early adopters and active media consumers, and finally, those who were none of those. A comparative analysis between these four groups was conducted using percentage of frequencies and means of Likert scale questions.

\section{FINDINGS AND ANALYSIS}

We have argued that one group of consumers may be more focused on the technological aspects of a product and another group on the social and content-related aspects. As described above, the first group is often called early adopters and we have chosen to call the second group active media consumers. Active media consumers have a high interest and consumption of new media that is accessible "anywhere and any time". Depending on the kind of innovation which is tested and introduced, one group or the other may be more important. Early adopters may be important for the introduction of the device itself, i.e. the technology, whereas active media consumers may be interested in the introduction of new media services. The cross-section between the groups is likely to be the most important for the introduction of new media technology. This third group we call engaged media users. Engaged media users is a blend of early adopters and active media consumers, i.e. they have a high interest in both new technology and active media consumption. We argue that a definition of these engaged media users provides possibilities for a better understanding of the development of media markets and a better management of service development in the media sector.

In this section we present the analysis from part three of the questionnaire. We have divided the presentation of the results in four categories of respondents, early adopters (648) active media consumers (288), engaged media users (393), and the others group (878). Figure 3 shows the distribution of early adopters and active media consumers within the data set.

In the following analysis we account for the preferences of issues related to the e-newspaper introduction for each group respectively. Further, we have divided the presentation of the results into three themes, i.e. content preferences, readiness to change, change to the printed edition, and willingness to pay for the e-newspaper. 
Figure 3: Distribution of Early Adopters, Active Media Consumers, and Engaged Media Users

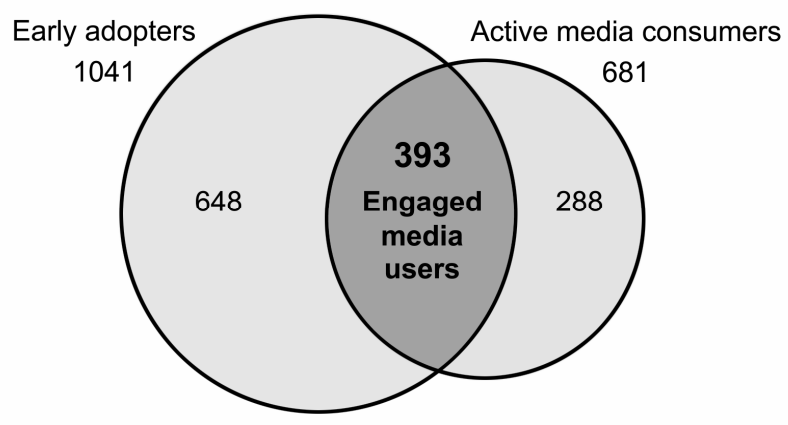

The three groups of consumers above together with the others group have similar distributions of age, occupation, income, education, and age. However, there is a difference in the distribution by gender (Table 3 ).

\section{Table 3. Distribution by Genders}

\begin{tabular}{|l|l|l|l|l|l|l|l|l|}
\hline Gender & \multicolumn{2}{|c|}{$\begin{array}{c}\text { Early } \\
\text { Adopters }\end{array}$} & \multicolumn{2}{c|}{$\begin{array}{c}\text { Active Media } \\
\text { Consumers }\end{array}$} & \multicolumn{2}{c|}{$\begin{array}{c}\text { Engaged Media } \\
\text { Users }\end{array}$} & \multicolumn{2}{c|}{ Others } \\
& Freq & $\%$ & Freq & $\%$ & Freq & $\%$ & Freq & $\%$ \\
\hline Men & 503 & 77,6 & 172 & 59,7 & 309 & 78,6 & 448 & 51,0 \\
\hline Women & 145 & 22,4 & 116 & 40,3 & 84 & 21,4 & 430 & 49,0 \\
\hline Total & 648 & 100 & 288 & 100 & 393 & 100 & 878 & 100 \\
\hline
\end{tabular}

The distribution of men and women in the others group is fairly even while there are more men than women in the other three. In the early adopter and engaged media users groups there are only slightly more than $20 \%$ women.

\section{Content preferences}

The content preferences theme concerns the added value services that users consider to be preferable together with the e-newspaper. Respondents were also asked about the reasons for their preferences. They rated the factors on a 7-point Likert scale where 1 represented not interesting and 7 very interesting. In table 4 the means per item is presented for each user group. 
Table 4: Mean Ratings of Preferred Added Service Value

\begin{tabular}{|c|c|c|c|c|}
\hline Added service value & $\begin{array}{c}\text { Early } \\
\text { Adopters }\end{array}$ & $\begin{array}{c}\text { Active } \\
\text { Media } \\
\text { Consumers }\end{array}$ & $\begin{array}{l}\text { Engaged } \\
\text { Media } \\
\text { Users }\end{array}$ & Others \\
\hline Personalized news & 5.58 & 5.27 & $\overline{5.84}$ & 5.21 \\
\hline $\begin{array}{l}\text { Community information (time } \\
\text { tables, maps) }\end{array}$ & 5.63 & 5.35 & 5.74 & 5.18 \\
\hline $\begin{array}{l}\text { Personal information (calender, } \\
\text { phone book) }\end{array}$ & 3.92 & 3.59 & 4.56 & 3.15 \\
\hline $\begin{array}{l}\text { General information (manuals, } \\
\text { Encyclopedia) }\end{array}$ & 4.64 & 4.65 & 5.18 & 4.26 \\
\hline Books and magazines & 4.15 & 4.30 & 4.79 & 3.73 \\
\hline News archive & 6.30 & 6.41 & 6.38 & 6.07 \\
\hline $\begin{array}{l}\text { Transactions (e-commerce, } \\
\text { bookings) }\end{array}$ & 4.65 & 4.35 & 5.11 & 3.92 \\
\hline Entertainment & 5.07 & 4.79 & 5.30 & 4.77 \\
\hline
\end{tabular}

This data shows that the three groups early adopters, active media consumers, and engaged media users generally have stronger preferences than the others group. All of the suggested added services were rated as less interesting by these respondents. The opinions are similar between the audience groups early adopters, active media consumers, and engaged media users. It is interesting to notice that news archive is considered the most interesting and that personal information the least interesting by all three groups. Overall the engaged media user group has the highest rating of preferred added value of the different services. This may be connected to influencing factors for exchange of the printed paper to the e-newspaper (Table 4), where this group rated added service value highest of the three groups. All in all, this data indicates that the three groups are all relevant to consider as initial target groups as they have similar strengths in preferences and that they all differ significantly to the others group.

The respondents were then asked to choose the one added service value suggested in the previous question that they found the most interesting. The percentage of respondents within each category that choose the different added service values is presented in Table 5 below.

It is interesting to notice the shift in ranking when the respondents had to choose between the added service values. The most important added service value for all four audience groups were personalized news followed by archives, and additional content such as community information and personal information. It is noticeable that the personal information is found much less interesting and news archive more interesting by active media consumers and the others group compared to the other groups. However, this data implies that the majority have similar patterns of prioritizing which in turn indicates that the offer of added value services can be uniform. 
Table 5: Preferred Added Service Value

\begin{tabular}{|c|c|c|c|c|}
\hline $\begin{array}{l}\text { Added Service } \\
\text { Value }\end{array}$ & $\begin{array}{c}\text { Early } \\
\text { Adopters }\end{array}$ & $\begin{array}{c}\text { Active Media } \\
\text { Consumers }\end{array}$ & $\begin{array}{l}\text { Engaged Media } \\
\text { Users }\end{array}$ & Others \\
\hline Personalized news & $52.3 \%$ & $46 \%$ & $53.2 \%$ & $48.1 \%$ \\
\hline $\begin{array}{l}\text { Community } \\
\text { information }\end{array}$ & $14 \%$ & $12 \%$ & $12.3 \%$ & $13.8 \%$ \\
\hline Personal information & $14 \%$ & $2.2 \%$ & $12.3 \%$ & $1.7 \%$ \\
\hline General information & $3.1 \%$ & $2.6 \%$ & $4.3 \%$ & $2.4 \%$ \\
\hline $\begin{array}{l}\text { Books and } \\
\text { magazines }\end{array}$ & $5 \%$ & $4.7 \%$ & $5.1 \%$ & $3.5 \%$ \\
\hline News archive & $15.2 \%$ & $22.3 \%$ & $14.3 \%$ & $21.1 \%$ \\
\hline Transactions & $2.8 \%$ & $3.3 \%$ & $2.8 \%$ & $1.3 \%$ \\
\hline Entertainment & $5 \%$ & $6.9 \%$ & $6.1 \%$ & $8.2 \%$ \\
\hline Total & $100 \%$ & $100 \%$ & $100 \%$ & $100 \%$ \\
\hline
\end{tabular}

The respondents were also asked about the reason for choosing that particular added value service. They were asked to rate the factors on a 7 -grade Likert scale where 1 represents do not agree and 7 agree. In Table 6 the means per item for each user group is presented.

Table 6: Reasons for Choosing Added Service Value

\begin{tabular}{|l|c|c|c|c|}
\hline \multicolumn{1}{|c|}{ Reasons } & $\begin{array}{c}\text { Early } \\
\text { Adopters }\end{array}$ & $\begin{array}{c}\text { Active Media } \\
\text { Consumers }\end{array}$ & $\begin{array}{c}\text { Engaged Media } \\
\text { Users }\end{array}$ & Others \\
\hline $\begin{array}{l}\text { Benefit greater } \\
\text { than cost }\end{array}$ & 4.89 & 5.16 & 5.24 & 4.63 \\
\hline Time saving & 5.47 & 5.71 & 5.86 & 5.09 \\
\hline $\begin{array}{l}\text { Provides valuable } \\
\text { information }\end{array}$ & 5.95 & 6.09 & 6.19 & 5.70 \\
\hline $\begin{array}{l}\text { Provides added } \\
\text { value }\end{array}$ & 5.89 & 6.01 & 6.19 & 5.60 \\
\hline $\begin{array}{l}\text { Interest in latest } \\
\text { services }\end{array}$ & 4.37 & 3.29 & 4.76 & 2.66 \\
\hline $\begin{array}{l}\text { Simplifies work } \\
\text { tasks }\end{array}$ & 3.55 & 3.76 & 4.34 & 2.64 \\
\hline
\end{tabular}

The ranking between the reasons is similar between the four groups. All consider valuable information, the added value, and time savings to be the most important reasons. Simplifying work tasks and interest in latest services are the least interesting reason for all groups. Nevertheless, there is an interesting difference, the others group has lower means for all suggested reasons. This is another indicator for presuming that the three groups early adopters, active media consumers, and engaged users are all relevant to consider as initial target groups.

\section{Readiness to Change}

The theme readiness to change concerns when the respondents believe they will be willing to read their newspaper on e-paper and if they would consider replacing the printed newspaper with a future e-newspaper. The theme also includes questions about the factors influencing the decisions. 
The respondents answered within which timeframe they believe they are prepared to read the newspaper on e-paper (Table 7).

Table 7: Time Frame

\begin{tabular}{|l|c|c|c|c|}
\hline Time frame & $\begin{array}{c}\text { Early } \\
\text { Adopters }\end{array}$ & $\begin{array}{c}\text { Active Media } \\
\text { Consumers }\end{array}$ & $\begin{array}{c}\text { Engaged Media } \\
\text { Users }\end{array}$ & Others \\
\hline Today & $71.4 \%$ & $54.1 \%$ & $78.6 \%$ & $43.6 \%$ \\
\hline Within 5 years & $21 \%$ & $27.2 \%$ & $16.4 \%$ & $30.1 \%$ \\
\hline Within 10 years & $4.4 \%$ & $9 \%$ & $4 \%$ & $11.4 \%$ \\
\hline Within 20 years & $1.2 \%$ & $2.5 \%$ & $0.5 \%$ & $3.9 \%$ \\
\hline Never & $2.0 \%$ & $7.2 \%$ & $0.5 \%$ & $11.0 \%$ \\
\hline Total & $100 \%$ & $100 \%$ & $100 \%$ & $100 \%$ \\
\hline
\end{tabular}

The group that is the most prepared to read the e-newspaper today is clearly engaged media users followed by early adopters and the majority of active media consumers are also prepared to read the newspaper on epaper today. The others group is more pending and as many as $11 \%$ of the respondents claim they will never read on e-paper.

The respondents were asked if they would consider exchanging their printed newspaper to an e-newspaper sometime in the future (Table 8).

Table 8: Willingness to Exchange

\begin{tabular}{|l|c|c|c|c|}
\hline \multicolumn{2}{|c|}{$\begin{array}{c}\text { Early } \\
\text { Adopters }\end{array}$} & $\begin{array}{c}\text { Active Media } \\
\text { Consumers }\end{array}$ & $\begin{array}{c}\text { Engaged Media } \\
\text { Users }\end{array}$ & Others \\
\hline Yes & $88.3 \%$ & $72.3 \%$ & $93.2 \%$ & $67.5 \%$ \\
\hline No & $11.7 \%$ & $27.7 \%$ & $6.8 \%$ & $32.5 \%$ \\
\hline Total & $100 \%$ & $100 \%$ & $100 \%$ & $100 \%$ \\
\hline
\end{tabular}

This result clearly shows that the engaged media users have the most positive attitude towards exchanging the printed newspaper into the e-newspaper. The most negative is the others group.

The respondents were then asked to rate factors that influence the willingness to exchange the printed newspaper with an e-newspaper. They answered on a 7 -grade Likert scale where 1 represents do not agree and 7 agree. In Table 9 the means per item for each user group and in Table 10 the ranking within each group are presented.

Table 9: Means of Ratings Concerning Influencing Factors for Exchange

\begin{tabular}{|l|c|c|c|c|}
\hline Factors & $\begin{array}{c}\text { Early } \\
\text { Adopters }\end{array}$ & $\begin{array}{c}\text { Active Media } \\
\text { Consumers }\end{array}$ & $\begin{array}{c}\text { Engaged } \\
\text { Media Users }\end{array}$ & Others \\
\hline Environmental reasons & 4.48 & 4.35 & 4.69 & 4.10 \\
\hline Economical savings & 5.23 & 4.86 & 5.48 & 4.50 \\
\hline Time savings & 5.36 & 4.75 & 5.87 & 4.09 \\
\hline Anytime anywhere access & 6.35 & 5.88 & 6.64 & 5.51 \\
\hline Added service value & 5.81 & 4.78 & 6.36 & 4.44 \\
\hline
\end{tabular}


As can be seen in Table 9, all items are rated lower by the others group. Early adopters rate all items higher than active media consumers. It is also noticeable that engaged media users in general rate these factors the highest. Table 10 shows the relative importance of different aspects of the e-newspaper for the adoption of the e-newspaper.

Table 10: Ranking of Influencing Factors for Exchange within Each Group

\begin{tabular}{|l|c|c|c|c|}
\hline Ranking & Early adopters & \multicolumn{1}{|c|}{$\begin{array}{c}\text { Active media } \\
\text { consumers }\end{array}$} & $\begin{array}{c}\text { Engaged media } \\
\text { users }\end{array}$ & Others \\
\hline 1 & $\begin{array}{c}\text { Anytime } \\
\text { anywhere } \\
\text { access }\end{array}$ & $\begin{array}{c}\text { Anytime } \\
\text { anywhere } \\
\text { access }\end{array}$ & $\begin{array}{c}\text { Anytime } \\
\text { anywhere } \\
\text { access }\end{array}$ & $\begin{array}{c}\text { Anytime } \\
\text { anywhere } \\
\text { access }\end{array}$ \\
\hline 2 & $\begin{array}{c}\text { Added service } \\
\text { value }\end{array}$ & $\begin{array}{c}\text { Economical } \\
\text { savings }\end{array}$ & $\begin{array}{c}\text { Added service } \\
\text { value }\end{array}$ & $\begin{array}{c}\text { Economical } \\
\text { savings }\end{array}$ \\
\hline 3 & TimeSavings & $\begin{array}{c}\text { Added service } \\
\text { value }\end{array}$ & TimeSavings & $\begin{array}{c}\text { Added service } \\
\text { value }\end{array}$ \\
\hline 4 & Economical & Time savings & $\begin{array}{c}\text { Economical } \\
\text { savings }\end{array}$ & $\begin{array}{c}\text { Environmental } \\
\text { reasons }\end{array}$ \\
\hline 5 & $\begin{array}{c}\text { Environmental } \\
\text { reasons }\end{array}$ & $\begin{array}{c}\text { Environmental } \\
\text { reasons }\end{array}$ & $\begin{array}{c}\text { Environmental } \\
\text { reasons }\end{array}$ & Time savings \\
\hline
\end{tabular}

All groups rate anytime anywhere access the most important. Economical savings and time savings are more important to active media consumers and the others group whereas added service value is rated higher by early adopters and engaged media users. Time savings is on third place for early adopters and engaged media users while active media consumers rank it as fourth and the others group as fifth. Environmental reason does not seem to be very important to any of the audience groups. All things considered, the pattern of factors influencing the adoption seems similar. Nonetheless, engaged media users show the strongest tendency of valuing these factors high.

The next question on this theme concerned the importance of different factors for choosing to read the e-newspaper. The respondents rated the factors on a 7-point Likert scale where 1 represents not important and 7 very important. In Table 11 the means per item is presented for each user group.

Table 11: Means of Rating of Importance of Factors for Choosing to Read the e-Newspaper

\begin{tabular}{|c|c|c|c|c|}
\hline Item & $\begin{array}{c}\text { Early } \\
\text { Adopters }\end{array}$ & $\begin{array}{l}\text { Active Media } \\
\text { Consumers }\end{array}$ & $\begin{array}{l}\text { Engaged Media } \\
\text { Users }\end{array}$ & Others \\
\hline Layout & 5.57 & 5.20 & 5.61 & $\overline{5.01}$ \\
\hline Continous updates & 6.37 & 6.45 & 6.55 & 6.00 \\
\hline Interactive functions & 4.44 & 4.01 & 5.05 & 3.51 \\
\hline Ease of use & 5.81 & 6.13 & 5.62 & 6.29 \\
\hline $\begin{array}{l}\text { Dependable } \\
\text { technique }\end{array}$ & 6.41 & 6.52 & 6.40 & 6.37 \\
\hline $\begin{array}{l}\text { Environmental } \\
\text { issues }\end{array}$ & 4.93 & 4.97 & 5.17 & 4.72 \\
\hline Easy navigation & 6.44 & 6.50 & 6.57 & 6.14 \\
\hline
\end{tabular}


Yet again all items are rated lower by the others group except for one, i.e. ease of use, which is rated the highest by this group. The interest for interactive functions and environmental factors is generally low whereas dependable technique, ease of use, easy navigation and updates are rated higher. This indicates that the influencing factors are more or less ranked in the same order even though they in general are considered more important by engaged media users.

\section{Willingness to pay}

The theme willingness to pay concerned attitudes towards cost levels and the financing of the e-reader device. The respondents were asked about the acceptable cost level for exchanging the printed newspaper with the e-newspaper (Table 12).

Table 12: Acceptable Cost Level for Exchange

\begin{tabular}{|l|c|c|c|c|}
\hline Cost level & $\begin{array}{c}\text { Early } \\
\text { Adopters }\end{array}$ & $\begin{array}{c}\text { Active Media } \\
\text { Consumers }\end{array}$ & $\begin{array}{c}\text { Engaged Media } \\
\text { Users }\end{array}$ & Others \\
\hline $\begin{array}{l}\text { Cheaper than } \\
\text { the printed } \\
\text { newspaper }\end{array}$ & $70 \%$ & $71.1 \%$ & $63.6 \%$ & $74.1 \%$ \\
\hline $\begin{array}{l}\text { Same price as } \\
\text { the printed } \\
\text { newspaper }\end{array}$ & $14.4 \%$ & $14.3 \%$ & $13.8 \%$ & $12.4 \%$ \\
\hline $\begin{array}{l}\text { Can be more } \\
\text { expensive if } \\
\text { providing added } \\
\text { value }\end{array}$ & $11.4 \%$ & $8.5 \%$ & $17.3 \%$ & $8 \%$ \\
\hline $\begin{array}{l}\text { Price is } \\
\text { unessential }\end{array}$ & $4.2 \%$ & $6.1 \%$ & & $5.5 \%$ \\
\hline Total & $100 \%$ & $100 \%$ & $100 \%$ & $100 \%$ \\
\hline
\end{tabular}

The accepted cost level is similar between the four groups. The engaged media users are slightly more inclined to accept a higher price if there is added value and are more accepting to a higher price than the other three groups. However, all four groups clearly indicate that they expect a lower price to consider exchanging the printed newspaper with the e-Reader device.

The next question on this theme regarded opinions about how the eReader device should be financed. The respondents were given three alternatives to choose from (Table 13).

The group most willing to purchase the e-reader device is the engaged media users and the active media consumers are the least willing to pay for the e-reader. The majority of all four audience groups think the e-newspaper should be free with a subscription, even though engaged media users do not think so to the same extent. 
Table 13: E-Reader Device Finance Models

\begin{tabular}{|l|c|c|c|l|}
\hline Finance model & Early Adopters & $\begin{array}{c}\text { Active Media } \\
\text { Consumers }\end{array}$ & $\begin{array}{c}\text { Engaged Media } \\
\text { Users }\end{array}$ & Others \\
\hline $\begin{array}{l}\text { Purchase by } \\
\text { instalments }\end{array}$ & $12.5 \%$ & $11.4 \%$ & $11.3 \%$ & $9.2 \%$ \\
\hline $\begin{array}{l}\text { Purchased by } \\
\text { the user }\end{array}$ & $27.5 \%$ & $23.8 \%$ & $32.4 \%$ & $25.1 \%$ \\
\hline $\begin{array}{l}\text { Free with a } \\
\text { newspaper } \\
\text { subscription }\end{array}$ & $60 \%$ & $64.8 \%$ & $56.3 \%$ & $65.6 \%$ \\
\hline & $100 \%$ & $100 \%$ & $100 \%$ & $100 \%$ \\
\hline
\end{tabular}

\section{DISCUSSION AND CONCLUSION}

In this paper, we have addressed the question of how to combine adoption theory with media consumption aspects to identify audience groups for parallel introduction of new technology and media services. We set out to experiment with different audience groups to study how they differ with respect to the adoption of new media services, combining early adopter profiles with social and content-related aspects of media services. This resulted in identifying interesting consumer groups for introducing new media technology together with new media services: (1) the traditional early adopter group, (2) active media consumers, and a very interesting new group (3) engaged media users.

In analyzing the results of our survey, we found some interesting differences between the early adopters, the active media consumers and the engaged media users compared to the others group. Regarding content preferences the three groups early adopters, active media consumers and engaged media users are similar, however the engaged media users have the strongest likelihood to exchange the printed newspaper for an e-newspaper. This is also the group with the strongest willingness to pay for the new offer. The group of engaged media users may be important as a segment for analysis when introducing new media offers that encompass technological as well as content and socially related aspects. Our analysis in this paper shows that active media consumers have as strong preferences as early adopters, but their preferences are slightly different. This makes them an important group to analyse separately from early adopters. We argue that the impact and use of this group may be the largest when introducing innovations with content (as opposed to strictly technology). The introduction of the third audience group, the engaged media users, allows us to analyze respondents that fit into both categories.

In this case, investigating preferences for a future e-newspaper, the content and socially related aspects were proven to be very important. We could also show that the active media consumer group have as strong preferences and interests as early adopters and that these aspect matter to the early adopter group as well as technological issues. The objective of the paper was to identify important audience groups that can be used as 
initial target groups for the introduction of the e-newspaper. We have discussed differences and similarities between different audience groups in order to shed light on possible strategies for the e-newspaper introduction.

We argue that the focus on early adopters, and thereby the technical aspects of a new innovation, is too limited when it comes to highly "mediated" products and services for which an important part of the product offering is related to the social values that consumers enjoy. As organizations tend to focus on the preferences of early adopters they are therefore limited in their approach. The preferences of active media consumers give way to a different kind of analysis which is complementary to that of Rogers' (1995). We believe that an expansion of Rogers' (1995) framework would be fruitful for a better understanding of the development of media markets and would offer better possibilities to manage the introduction of new media technologies and new media services. Broadening the technology focus with social and content related aspects of media services gives a more comprehensive analysis, and thus is more likely to correspond to the audience adoption patterns.

How does this improve our previous understanding? The prime gain from using the framework of early adopters is the time span between the early adopters' use of a new product or service and that of the mass market. Organizations can hence adapt to this prognosis of future market preferences and adjust its products and product portfolio. The behavior of early adopters remains important for the introduction of new technological functions in products. But as shown in this paper there are other groups to consider when it comes to the introduction of a new media product or service. Considering the group of active media consumers for instance builds on the existence of expert consumers that are high up in what one may call a "consumption hierarchy" (Rogers 1995). These consumers are characterized by a high degree of consumption or use of their products. Instead of gaining time (as with early adopters) to adjust product attributes and the product portfolio, the active media consumers give way to an understanding of the potential consumption hierarchy for a new product in connection to its use. If companies organize their product portfolio in accordance, this means that they differentiate products and services on price, prestige, communication intensity, or other dimensions of the social value of innovations. For novices, there is a basic set of consumption possibilities. For more advanced consumers, there are add-ons to be consumed, generating a pyramid of consumption possibilities. The consumption by those at the top of the pyramid have prognostic value for the social aspects of the new media forms, as we can assume that they through their preferences are more aware of the social value of the media, and hence will examine those aspects more critically when faced with new media.

Our analysis is based on data from the newspaper industry. It has been acknowledged, however, that more and more products or services 
also in other industries are becoming mediated. Beside the technical aspects of the products their content is becoming increasingly important (Normann \& Ramírez 1994; Normann 2001). In a mobile phone, the communication facilities are of crucial importance but the mobile phones business of today is relying on media content. Thereby the adoption of new mobile phones is influenced both by the technical innovation and the media content.

We therefore suggest that one possible strategy for new media products and services that may benefit organizations is to seek out the engaged media users to find a foothold in the market. Such would be the case also for the e-newspaper. Further research should dig deeper into the characteristics and adoption patterns of audience groups such as engaged media users and active media consumers, and to compare them with those of early adopters. This would be useful to further understand the market potential of an e-newspaper, but also for other media products or services.

\section{REFERENCES}

Arnould, E. J., \& L. L. Price (1993). River Magic: Extraordinary Experience and the Extended Service Encounter. Journal of Consumer Research 20(1): 24-45.

Balasubramanian, S., \& V. Mahajan (2001). The Economic Leverage of the Virtual Community. International Journal of Electronic Commerce 5(3): 103-138.

Bazalgette P. (2005). Billion Dollar Game: How Three Men Risked It All and Changed the Face of Television. London: Time Warner Book

Bettman, J. R., \& Sujan, M. (1987). Effects of Framing on Evaluation of Comparable and Noncomparable Alternatives by Expert and Novice Consumers. Journal of Consumer Research 14(2): 141-144.

Buchanan, T., \& Smith, J. L. (1999). Using the Internet for psychological research: Personality testing on the World-Wide Web. British Journal of Psychology, 90: 125144.

Calder, B. J., \& E. C. Malthouse (2004). Qualitative Media Measures: Newspaper Experiences. International Journal on Media Management 6(1\&2): 123-130.

Dahlsten F. (2004). Managing Customer Knowledge: Towards Market Orientation and Innovation in an Automotive Organization. Gothenburg: Chalmers University of Technology

Danneels E. (2003). Tight-Loose Coupling with Customers: The Enactment of Customer Orientation. Strategic Management Journal 24: 559-576

Deery, J. (2003). TV.com: Participatory viewing on the Web. Journal of Popular Culture 37(2): 161-183.

Fredberg, T., \& S. Ollila (2005). Big Brother: Analyzing the media system around a reality TV-show. Growth and Dynamics of Maturing New Media Companies. C. dal Zotto. Jönköping, JIBS Research Reports. 
Hagel III, J., \& A. G. Armstrong (1997). Net Gain: Expanding Markets through Virtual Communities. Boston, Mass. Harvard Business School Press.

Hair, J. F., Black, B., Babin, B., Anderson, R. E., \& Tatham, R. L. (2005). Multivariate Data Analysis. Prentice Hall, Upper Saddle River, N.J.

Ihlström, C., \& Henfridsson, O. (2005). Online Newspapers in Scandinavia: A Longitudinal Study of Genre Change and Interdependency. IT \& People, 18(2): 172-192.

Ihlström, C., \& Palmer, J. (2002). Revenues for Online Newspapers: Owner and User Perceptions. Electronic Markets: the International Journal of Electronic Commerce \& Business Media, 12(4): 228-236.

Ihlström, C., Åkesson, M., \& Nordqvist, S. (2004). From Print to Web to e-paper - the challenge of designing the e-newspaper. In Proceedings of ICCC 8th International Conference on Electronic Publishing, ELPUB 2004, Brasilia, 249-260.

Jenkins, A. M. (1985). Research Methodologies and MIS Research. In Research Methods in Information Systems, E. Mumford et al. (Ed.), Elsevier Science Publishers B.V., Amsterdam, Holland, pp. 103-117.

Johansson, T. (2002). Lighting the Campfire: The creation of a community of interest around a media company. International Journal on Media Management 4(1): 4-12.

Normann, R. (2001). Reframing Business. When the Map Changes the Landscape. Chichester, Wiley.

Normann, R., \& R. Ramírez (1994). Designing Interactive Strategy: From Value Chain to Value Constellation. Chichester, John Wiley \& Sons.

Park, R.E. (1923). The Natural History of the Newspaper. American Journal of Sociology 29(3): 273-289

Pine II, B. J., \& J. H. Gilmore (1999). The Experience Economy. Boston, MA, Harvard Business School Press.

Prahalad, C. K., \& V. Ramaswamy (2003). The New Frontier of Experience Innovation. MIT Sloan Management Review 44(4): 12-18.

Rogers, E. M. (1995). Diffusion of innovations. New York, The Free Press.

Singer, J. B., Tharp, M. P., \& Haruta, A. (1999). Online staffers: Superstars or second-class citizens? Newspaper Research Journal, 20(3): 29-47.

Singer, J. B. (2002). Information Trumps Interaction In Local Papers' Online Caucus Coverage. Newspaper Research Journal, 23(4): 91-96.

Underwood, D. (1995). When MBAs rule the Newsroom. New York: Columbia University Press.

Webster, J. G. (1998). The Audience. Journal of Broadcasting and Electronic Media 42(2): 190-197.

Verganti R. (2005). Managing Design Driven Innovation: Innovation Strategies in Italian Design-Intensive Manufacturers. Keynote address, European Academy of Management Conference, May 6, 2005

Vigneron, F. \& L. W. Johnson (1999). A Review and a Conceptual Framework of PrestigeSeeking Behaviour. Academy of Marketing Science Review 1999(1): 1-15. 
Weibull, L. \& Wadbring, I. (2000). Att studera dagspressen i Sverige - utgångspunkter. In L. Weibull \& I. Wadbring (Eds.), Tryckt. 20 kapitel om dagstidningar $i$ början på 2000talet. Göteborg: Institutionen för Journalistik och Masskommunikation, Göteborgs Universitet, Sweden.

Ziv, N. D. (2005). Towards a New Paradigm of Innovation on the Mobile Platform: Redefining the Roles of Content Providers, Technology Companies, and Users. In Proceedings of the International Conference on Mobile Business (ICMB'05), Sydney, Australia.

\section{Internet references}

E Ink (2006), retrieved 20 February 2006 from http://www.eink.com

Fujitsu (2005), retrieved 3 March 2006 from http://www.fujitsu.com/global/news/pr/ archives/month/2005/20050713-01.html

Sfgate.com (2006), retrieved 20 December 2006 from http://sfgate.com/cgibin/article.cgi?f=/c/a/2005/11/07/BUGP0FIINV1.DTL

Techworld (2006), retrieved 20 December 2006 from http://www.techworld.nl/idgns/ 1797/color-e-paper-trials-begin-on-tokyo-trains.html

iRex (2006), retrieved 19 December 2006 from http://www.irextechnologies.com

Plastic Logic (2006), retrieved 3 March 2006 from http://www.plasticlogic.com/ downloads/usdc06-presented-9-web.pdf

Polymer Vision (2006), retrieved 3 March 2006 from http://www.polymervision.com

Sony (2006), retrieved 19 December 2006 from http://www.learningcenter.sony.us/ assets/pa/prs/index.html

Tianjin Jinke (2006), retrieved 25 August 2006 from http://www.jinke.com.cn/compagesql/ English/embedpro/prodetail.asp?id=20

Vnunet.com (2006), retrieved 20 December 2006 from http://www.vnunet.com/vnunet/ news/2143990/flexible-tv-coming-package-near

IFRA eNews initiative (2006), retreived 18 December 2006 from http://www.ifra.com/ website/website.nsf/html/CONT_ENEWS?OpenDocument\&ENW 
